\title{
The founding of the semigroup forum on the 50th anniversary of its formation
}

\section{Paul S. Mostert ${ }^{1}$}

Received: 21 March 2019 / Accepted: 6 September 2019 / Published online: 11 October 2019

(c) Springer Science+Business Media, LLC, part of Springer Nature 2019

The birth of a periodical dates to its first issue. By that measure, the 50th birthday of the Semigroup Forum occurs in 2020.

But periodicals do not burst forth in the full blush of life. There is first the idea, a period of gestation of the idea, a call for action on the part of someone or some group to organize the framework, the organization of an editorial board, the search for a publisher, a call for papers, the receipt and refereeing of those papers, back and forth communication between authors and editors to reach a final form for each submitted paper suitable for publication, and then the selection of papers for the first issue. This article is about how that came about, when the seminal idea was first put forward and actual first steps taken to bring about the creation of the Semigroup Forum. That began in July of 1968 at the end of the First International Symposium on Semigroups (FISS), held in the Smolenice Castle in Czechoslovakia exactly one month before the invasion by Soviet-Bloc forces that brought an end to the Prague Spring.

With considerable trepidation, I will relate that history and some perhaps surprising facts about the role played by the Semigroup Forum and its formation, editors, and writers in the cultural interchange of ideas across the Iron Curtain during the Cold War.

Voltaire looked upon historical record with a jaundiced eye. Memory is both fleeting and constructive, hence, at best, uncertain, an "uncomfortable position." The facts I present must, in some cases, be taken as subject to correction, though I have tried to verify to the extent possible. I welcome any information others can share that will help illuminate the history of mathematics and science during this very important era between the death of Joseph V. Stalin in 1953 to the end of the Cold War in 1989.

The germ of the idea is uncertain. Some have said that there was talk about the need for a means to share ideas and results more easily and quickly among the fast grow-

\section{Dedicated to Alfred H. Clifford, Karl H. Hofmann, Boris M. Schein, Štefan Schwarz, and Klaus Peters.}

\section{Communicated by Jimmie D. Lawson.}

Paul S. Mostert

psmostert@twc.com

1 University of Kansas, Lawrence, Kansas, USA 
ing population of semigroup aficionados around the world at the 1966 International Congress of Mathematicians in Moscow (ICM 1966).

There can be no doubt it was at that ICM 1966 that a major impediment to the ease of information flow across the East/West divide was relaxed. Mathematics was flourishing within the Soviet Union at the time, attractive as it was to highly-gifted minds eager to find an intellectual path least resistant to political friction. Semigroup theory was riding the crest of that wave. At the beginning of that Congress and before, mathematicians residing in the Soviet Union were required to write their papers and deliver their presentations in the Russian language. Few western mathematicians were competent at any level in the language. While communication across the Iron Curtain might attract political approbation in either direction, the consequences on the East side were potentially the more hazardous. Nevertheless, mathematicians on both sides were equally desirous of a freer flow of information.

Privately, as significant contact between Eastern-Block and Western-Block mathematicians grew, the Russian-only language limitations were not at all popular. Shortly before the Congress, at a meeting in Estonia attended by a number of algebraists from outside the Eastern-block, a certain session was chaired by the Yugoslav mathematician, G. CUPONA. After a couple of minutes into BorIS M. SCHEIN's talk, by pre-arrangement, CUPONA interrupted him to suggest that, since it was well known that SCHEIN was fluent in English, and most of the audience was conversant in the language, would he please continue his talk in that language.

It was decided to employ a similar trick at the ICM 1966 by asking a number of foreign mathematicians to complain about the lack in effective communication these rules caused and how they might be improved by allowing some kind of summary in another language. SCHEIN had been asked by the Moscow algebraist, L. A. SKORNYAKOV, to help with sessions on Boolean algebras and lattices to see that they were adequately supplied with needs for chairs, chalk, etc. In doing so, he came into contact with some of the politically sensitive apparatchiks charged with, among other things, insuring that the host country made their foreign guests comfortable. After SCHEIN's mention of the complaints to them, the word came down that summaries should be delivered in German, French, or English.

Further relaxation came in later meetings where foreign mathematicians were present. By the time of the First International Symposium on Semigroups, held June 17-22, 1968 in the castle of Smolenice near Bratislava in what was then Czechoslovakia, organized by ŠTEFAN SCHWARZ, and held during the Prague Spring under Alexander Dubček, with the free flow of information and bonding of friendships across the seemingly melting Iron Curtain, the ground was right for the seed to take root. And it did.

Fluent in a number of languages, ScHWARZ, at the time, serving both as President of the Slovak Academy of Sciences and Vice President of the Czechoslovak Academy of Sciences, had considerable influence within the scientific community in Czechoslovakia and communicated with many mathematicians throughout the world in their own language, which became immensely easier to do due to his position and the more relaxed political environment under Dubček. Among those 
with whom he communicated ${ }^{1}$ were A. H. Clifford, K. H. HofmAnN and me, all at Tulane University in New Orleans, though more intensely with CLIFFORD, who was the more senior, more closely aligned with SCHWARZ's mathematical interests, and more prominent at the time. The three of us had a number of communications back and forth in 1967 during his planning for the 1968 Smolenice meeting. Some of those were shared (virtually all of those to HoFMANN and me were), but others were directed specifically to CLIFFORD. None of those that I retained or that were later found by others carried a hint of any thoughts other than of the intense interest SCHWARZ had to further communication among the worldwide semigroup community. He had already, seventeen years earlier, founded the Mathematico-Physical Journal of the Slovak Academy of Sciences. Thinking in terms of a new mathematics journal was certainly not alien to him. But I was, and am, unaware of any specific statement of his, or of anyone's, that there was any thought, prior to the 1968 Symposium, about the creation of a journal specific to semigroup theory. He certainly set the stage by his organization of the Smolenice meeting.

Near the end of that meeting, CLIFFORD, HOFMANN and I were approached by a relatively large contingent of attendees that included SCHWARZ and mathematicians representative of the wide nationalities present at the meeting. I remember only a few specifically, but I do remember B. M. SCHEIN and L. M. GLUSKIN from the USSR specifically, two that we had met and with whom we held long, interesting, free-flowing discussions at the ICM1966, well lubricated as we were from a bottle of Armenian cognac on one occasion and Russian vodka on another. Already the group had decided that such a venture should be accomplished and that the three of us were the ones to be charged with getting it done. Neither HOFMANN nor I were aware that such discussions had taken place and CLIFFORD showed no signs that he knew. It seems to have come to us all as something of a surprise. We agreed to explore the matter to see what could be accomplished.

The mechanism contemplated was left somewhat nebulous. Indeed, it seemed that a formal journal was not thought necessarily the answer, but some kind of new vehicle, like a Rundbrief circulated more or less informally among the semigroup community. There were three desirable qualities expressed that it should have: (1) that the publication be restricted to semigroups of the algebraic and topological kind; (2) that it have quick turnaround-that is, there should be minimal time between submission and publication; and (3) it should be as much as possible in the nature of a forum,

\footnotetext{
1 Much of ScHWARZ's enormous paper legacy has, over the years, been winnowed down by sometimes overly aggressive secretarial efficiency. Professor OTAKAR GROŠEK (Slovak University of Technology in Bratislava) has been given the honor and opportunity to examine what remains of that legacy. He has shared with me the excerpts from the main correspondence that he has found concerning the 1968 Smolenice Symposium. The earliest letter mentioning his intention of organizing that Symposium was in a handwritten letter to K. H. HoFMANN and me dated March 5, 1967, quickly followed by a more comprehensive one to A. H. ClifFord dated March 11, 1967 in which ScHwARZ states his intention, "after consulting with CLIFFORD and LJAPIN" during the 1966 World Congress in Moscow, to organize an "International Symposium" with 40-50 participants. It may be that the very first letter about his intent was the one he wrote to K. H. HOFMANN and me just five days earlier. We also received a more formal notification on March 20, 1967. ClifFORD, HOFMANN, and I responded with a joint letter with our recommendations of participants.
} 
where short observations, questions and longer expositions and book reviews could be published. Otherwise, we were given free rein to get the job done.

As it happened, I had just contracted with Springer Verlag to publish the report of the month-long 1967 Conference on Transformation Groups, the editing for which I had finished in May of 1968. Already, in the mid 1960s and hardly having established himself after his Habilitation in 1963 (on the committee for which I had the honor to serve), K. H. HOFMANN had struck up a friendship and lively correspondence with the innovative editor and part owner, KLAUS PETERS, of Springer Verlag, who had already conceived of and executed the beginning of the author-generated Lecture Notes in Mathematics, (first issue 1964) and Manuscripta Mathematica, a journal which in his words "provides a forum for the rapid publication of advances in mathematical research" (with first issue scheduled to appear in 1969). That, perhaps, had some influence on the name chosen for the Semigroup Forum. Indeed, it was this close friendship that rebounded to my selection of Springer-Verlag as publisher of the Proceedings of the Conference on Transformation Groups, New Orleans 1967. It was natural for us to bring up the matter of the creation of Semigroup Forum with KLAUS PETERS.

PETERS found the idea for the Semigroup Forum appealing and potentially something that might be useful in other subject areas of mathematics and the sciences. He worked patiently with us to explain the needs and limitations in making an issue ready for publication and with the design and organization of the operation to suit our needs and interests to the publisher's. He took a big chance with us and has been a highly valued contributor to the success of the Semigroup Forum, working with us through several evolutionary steps brought about by advances in the technology for printing writer-prepared manuscripts from the original photocopying of author-typed manuscripts to the current use of TeX. To a person of PETERS' personal sensitivity to artful presentation the first issue could only have been tolerated as that of an understanding grandparent of the issue of proud parents presenting an ugly first child with hopes that, with age, it will grow into something more presentable.

We put together the first editorial board largely from the list of those invited to deliver talks at the Smolenice meeting. Of the 22 original members of the board, thirteen had been in attendance at the Smolenice symposium. Virtually all of the remaining nine had been on the list to be invited, but, for one reason or another, had been unable to attend.

The editorial board was designed so as to delineate and be representative of the full breadth of the mathematics and ethnicity within the active semigroup community for which it was to serve. Any editor could accept a paper and communicate it to the appropriate Managing Editor (CLIFFORD for papers in the algebraic theory, HOFMANN or me for other than purely algebraic.) While it was the communicating editor who was expected to either referee papers he communicated himself or have them refereed by appropriate experts, sometimes a Managing Editor would suggest changes, or even rejection of a paper. In fact, the usually diplomatic and accommodating AL CLIFFORD asked one author with a particularly abstruse and incorrigible style to discontinue submitting his work to Semigroup Forum. 
Because HOFMANN and I worked so closely together, indeed, we often were referred to as Hofmos ${ }^{2}$ by workers in the areas in which we worked, the two of us serving as Managing Editors may have been, as some thought, an over-representation on the topological side of the ledger. We had, however, separate skill sets that worked well in tandem and particularly well for organization and administration of the needs of the early years of the Forum.

One of the Managing Editors had to be the point-person who assembled each issue of the Forum and prepared it for being printed. This required a good deal of correspondence with other editors and the publisher as well as some final oversight of the contributions to make sure that they were correctly formatted for the photo-offset printing of the author-prepared typescripts then used. Sometimes typescripts had to be re-typed simply because the author did not have access to a suitable typewriter. In that process, we sometimes would correct typographical errors or clarify an awkward sentence where the author's facility with the English language was found wanting. We didn't originally have a name for this person, but finally settled on the term Executive Editor. CLIFFORD took on that job initially, but after three years, it was handed over to me and I served in that capacity for the next eleven years (1973-1984), at which time HOFMANN became Executive Editor. Three of the initial board of editors were citizens of the USSR: GLUSKIN, SCHEIN, and WAGNER. Also LJAPIN had been invited, but, having had an unfortunate experience with Soviet authorities and been warned that he had too much correspondence with people in the West, and not wishing to test Soviet authorities, ${ }^{3}$ declined. It is said that he regretted not having been on the original board of editors for the rest of his life. Official policy was that permission had to be requested and granted. The other three accepted without seeking permission.

Bureaucracy was a difficult and uncertain territory to navigate for the Soviet citizen during the Cold War. It could at times be made particularly onerous for the academic who wished to participate in an international exchange of ideas. Indeed, attendance by Soviet mathematicians at foreign (especially at Western) conferences and even to write publications in foreign journals had been so discouraged that both had almost disappeared by 1957. It was not clear to LJAPIN, or, perhaps, to anyone, just who it was that he had to ask for permission to serve as an editor of a foreign journal and he feared even inquiring about that might place him in an unfavorable light.

In the face of these bureaucratic pressures, the Forum seemed to stimulate and encourage the semigroup community in the Soviet Union to nonetheless work toward greater international contact and interaction. With the first article in the first issue, SCHEIN set the tone with a 62-page article-written in English.

Other authors in the Soviet Union followed suit. Few, if any, had the facility with the language that SCHEIN had. As a result, many such papers were funneled through SCHEIN so that he could polish up the language, as well as serve as communicating

\footnotetext{
2 This is a RoBerT J. KOCH originated play on the word hormos which we introduced in our Elements of Compact Semigroups (1966) to describe a certain linear chaining algorithm. It had been suggested to us by our Tulane colleague FRANK D. QUIGLEY who had a love for classical arts and languages.

3 Very likely, for a foreign editorship, the International Department (ID) of the Party, a particularly zealous promoter and protector of the Soviet way, would have to get in the act. With the backlash freeze to the ending of the Prague Spring, it is doubtful that any of the four candidates could have, in 1969, survived had he sought official permission.
} 
editor. Indeed, he served as a Managing Editor without Portfolio, an invaluable aid to the early years of the Forum's existence. Unfortunately, the politics of the time made it unwise to make it official. Anti-Semitism was, though not universal at the time, rampant in the Soviet Union; he was young; he pushed the boundaries of Soviet tolerance with his voluminous foreign correspondence; he was outspoken with a wry wit that was not always well received. It was not long before he was attracting unwanted attention. On a couple of occasions, I received an envelope from him containing nothing but propaganda pamphlets where I was expecting a mathematical manuscript. The American Mathematical Society's editor for the Reviews, also, received such a packet. Interestingly, the envelopes showed no signs of having been opened. But both of those I received had originally been mailed by him with mathematical manuscripts. I was told that the one addressed to the American Mathematical Society, also, started its journey carrying a mathematical manuscript and that the envelope was missing that manuscript when it arrived at its destination. We had to take care to send mail in plain letter-size envelopes and have it certified with return receipt in order to avoid as much of this as possible. Then he was told to stop sending and receiving so much foreign mail.

Ultimately, SCHEIN's ability to function was made intolerable. After his parents died and the Soviet Union signed the Helsinki Accords Final Act of 1975, SCHEIN decided to emigrate. After many delays and fights with the authorities, he and his family were able to leave the country. After temporary visits in Vienna and Tulane University in New Orleans, where he received considerable support, both financial and otherwise, from the mathematical, in particular the semigroup, community, he was able to settle in as a professor at the University of Arkansas.

Semigroup Forum suffered some relatively minor repercussions from the matter in that a few papers by mathematicians in the USSR were withdrawn and for a short while some authors felt the bite of official disapprobation, but at no point did Semigroup Forum lack for either editors or contributions of mathematicians from the Soviet Union. SCHEIN remained and still remains a valuable editor, the only one of the original board of editors in 2018, his 50th year of service to the Semigroup Forum. Likewise LEV N. SHEVRIN, who became an editor only few years later and is still on the editorial board, has accomplished a lot in assisting Soviet semigroup theorists to publish abroad in Semigroup Forum and elsewhere; he has also invested significant efforts in correcting the style and the English of such papers.

The formation of the Semigroup Forum represented a distinctive pioneering effort in the world of publications: After the monograph series of the Lecture Notes in Mathematics it was apparently the first journal to make use of photo-reproduction of author-generated typescripts (and thereby to abandon a time-honored editorial mandate of uniformity of typographical appearance in an otherwise formal professional journal, and then, later, led the way in restoration of the mandate by its adoption of the $\mathrm{T}_{\mathrm{E}} \mathrm{X}$ typesetting requirement of authors' manuscripts). It was one of the early publications devoted to a relatively narrow interest group of mathematicians, or, indeed, of any specialized area within the scientific community. And, surely, the fact that its original editorial board contained no less than eight editors from Iron-Curtain countries still under strict communistic control could not but add to its distinctiveness for its time! 
Although Springer was a private publisher seeking to make money, it was not solely profit-making that motivated KLAUS PETERS. PETERS had a strong dedication to the furtherance of artful, efficient and useful information exchange among scientific researchers the world over. While the early Semigroup Forum text was anything but artful, he was willing to suffer that inconvenience temporarily for the speed and timeliness desired by the semigroup community while awaiting the printing technology to catch up. $\mathrm{T}_{\mathrm{E}} \mathrm{X}$ would eventually remove that blemish. He strove to produce the best that could be accomplished within the constraints imposed by circumstances and needs of the day. I always kept one secretary busy retyping a manuscript for an author who lacked one capable of producing readable print, as did other Managing Editors.

No one need be reminded why KARL H. HOFMANN would be among those to whom this article is dedicated. No one has contributed more to the Semigroup Forum's existence, its quality, its expansion into other areas where semigroups play an important role and, indeed, to the subject of topological semigroups and to its history as it has appeared on the pages of the Semigroup Forum. Yes, and he brought in MiCHAEL MisLOVE to help transform the typescript to its more artistic and pleasing form. And no one has contributed more to the guidance of the Semigroup Forum's policies and organization from its very existence to its current state over a period of some 50 years and counting.

The First Symposium on Semigroups at Smolenice was an initial step and the inspiration for Semigroup Forum. Together they brought about the transcendence of a commonality of intellectual pursuit over the barriers of geography, politics, ethnicity and other impairments that can interfere with a free exchange of ideas among a highly diverse group of individuals. Yes, the Semigroup Forum can be counted as nothing less than a resounding success. With its international and fluid editorial board, Semigroup Forum has expanded and deepened the bonding of the semigroup community that began in Smolenice the week of June 16th of 1968.

Publisher's Note Springer Nature remains neutral with regard to jurisdictional claims in published maps and institutional affiliations. 